\title{
The dangerous role of politics in modern millennial movements
}

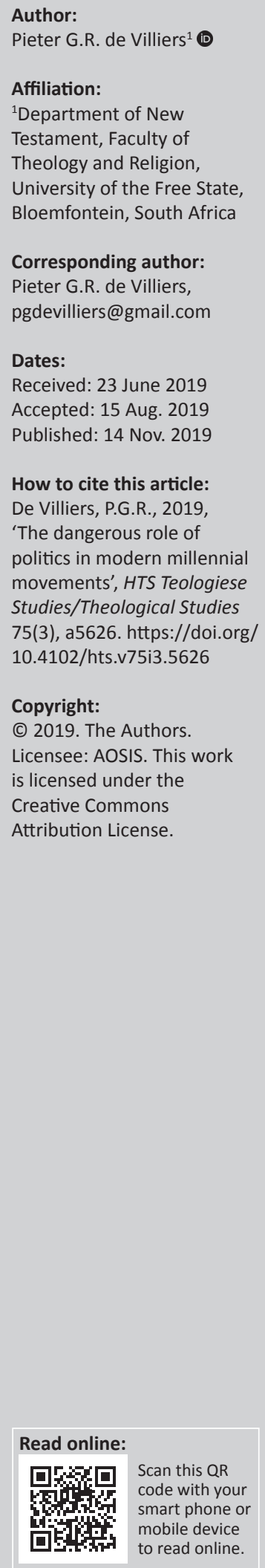

This article investigates the political nature and involvement of millennialism as a religious phenomenon. It, firstly, offers a brief analysis of how millennialism shifted from a significant, but marginal role player in the history of Christianity to become part of the mainstream religious discourse in recent times. It then seeks to explain how this came about by analysing the way this development continues and resonates with the political language and thought of the 19th-century religious discourse in the United States and in early modern England since the 16th century. It finally investigates the dangerous consequences of politicising eschatology by specifically analysing the role of Israel in millennial expectations.

Keywords: millennium; millennialism; millenarianism; chiliasm; left-behind literature.

\section{From apolitical to political millennialism ${ }^{1}$}

Millennialism was a major trend in the Jewish and Christian discourse in Western Europe and North America towards the end of the 20th century. ${ }^{2}$ It had an extraordinary interest in eschatological motifs like the thousand-year reign of peace, introduced by the rapture of the saints, Armageddon as the last war of the Antichrist between good and evil, the last judgement and the final eradication of evil.

This trend in modern times was not new. The expectation of a future time of bliss was always a firm belief of certain Christian groups with millennial expectations. Millennialism, also known as chiliasm, was so named after the reign of thousand years that was characteristic of this trend and that was based primarily on the enigmatic passage in Revelation 20:1-6 about such a reign of a thousand years in end times. Several of the earliest interpreters of Revelation, including wellknown authors from the 2nd century onwards, like Justin Martyr (Dial. Tryph. 31), Irenaeus (Adv. Haer. 4.8.11) and Tertullian (Adv. Mar. 3.7, 4.10-11), read this passage literally as foretelling the thousand-year reign of peace. ${ }^{3}$ Despite its prominence in some times and places and the common interest of the Christian tradition in eschatology, millennialism was in many instances mostly appropriated by groups on the margins of society or by individuals with a particular interpretation strategy of biblical texts or with a preoccupation with the unfolding of future events. For the rest, millennialism, and chiliasm as its corollary, was virtually unknown or downplayed in mainstream Christianity. In many instances, it was regarded as a marginal issue, or as a matter of personal conviction that was 'tolerated' by mainstream churches.

Matters changed radically when millennialism reappeared in the 20th century, initially as a doctrine amongst evangelical faith communities in Anglo-American settings. These groups, claiming the Bible as the highest authority about the future, studied eschatological passages to learn more about and prepare for the end times. Their interest in millennialism was driven by a spiritual desire to live an upright life to share in the future bliss promised to the faithful. From this time onwards these groups became more assertive about the centrality of millennialist beliefs for 1.See the discussion in Popkin (2001:vii-xiv) who investigates the millennium motif in a wider context. He remarks at the beginning of this
article: 'Within Judaism and Christianity there has always been a great expectation that something monumental would happen that would
transform human existence and bring an end to human history as we know it'. Of special relevance for this article is the discussion (Popkin
(2001:viii) on the history of millennialism in late Middle Ages and Early Modern Europe. Also important is the interchange between Jewish
and Christian receptions of the millennium since the 15th century. The surge in millennialism in the period was a result of the turbulent
times that included the forced conversion of Jews in Spain, the collapse of the Moorish kingdom and the expulsion of Jews from Spain and
Portugal, the discovery of the New World, the eruption of reform movements and many others (Popkin 2001:1x). Given the integration of
various countries in Europe, it is then said that millennialism would surface in other places like England, the Netherlands and Sweden. For
the role of Revelation as book about the future and the political readings it generated, see Maier (2003:1-7) and De Villiers (2019). Ebrard, Rothe, Hofmann, Delitzsch, Kurtz and others as its influential representatives.

3.See for some of the main representatives of this position in early Christianity the succinct overview by Kovacs and Rowland (2004:200-204).

Note: The collection entitled 'Eben Scheffler Festschrift', sub-edited by Jurie H. le Roux (University of Pretoria) and Christo Lombaard (University of South Africa). 
the life of the church. For them millennialism represents a key biblical teaching of great significance. Whoever questions their interpretation of its place and role in the Bible would be vilified as part of churches that have been corrupted by modernist exegesis and liberal theologies. Such churches were regarded as heretical were regarded as heretical, deviating from the truth and therefore resembling the unfaithful churches in Revelations 2-3 that held on to heresies and lead an immoral life. The attitude of millennialist thinkers towards those who differed from them was intense, reflecting the binary thinking of the Book of Revelation that vilified opponents as embodying the evil of the end times. ${ }^{4}$

This development shifted millennialism from the margins to the centre of attention, often to such an extent that it dominated the contemporary religious discourse, as will be pointed out below. It did not distract most of these groups that the predictions of millennialist prophets about end events consistently failed to realise or that there were so many different and contradictory forms of millennialism. Except for positions like amillennialism, postmillennialism and premillennialism, there are, as the contents page in Benware's book (2006) reveals, also various visions of the rapture, such as a pretribulational rapture, post-tribulation rapture, partial rapture, midtribulational rapture and a prewrath rapture. For the outside observer, this often bewildering debate about different millennialist visions and approaches may indicate that it is a movement that is mostly religious in nature, with a strong speculative interest in the future fate of individuals and communities. In general, the priority for many faith communities seems to have been to gain more knowledge about this matter, with the result that one could easily think that millennialism is apolitical and less interested in larger social matters and issues. This seems to be confirmed by its pessimistic outlook on the present dispensation and world that seems to indicate that millennialists have given up on this world. In the words of Judis (2005):

Christians who adhered to this theory believed that their main task on earth was to lead model lives so that they could be raptured before the tribulation. For most of the last century, many of them eschewed politics and had no view of foreign policy, except for a strong interest in the Jewish return to Israel. (p. 6)

This situation changed dramatically, especially in the second half of the 20th century. The increase is reflected in, but also promoted further by, a number of publications on the millennium that began to appear, with, as the most notable, the so-called 'Left Behind' books by best-selling authors like Jack Van Impe, John Hagee, Hal Lindsay and Tim LaHaye. These books presented a sensational, tense scenario that will begin with the rapture of an elect number of Christians who will be taken up from the earth to join Christ in the air and remain with him for a thousand years (1 Th 4:17-18). Only a select few will be raptured. Others will be 'left behind' to wage war against the Antichrist for 7 years. This will be the time of tribulations, consisting of terrible wars that will affect the whole world, with all the major world empires plotting against

4.Like Darby, the well-known defender of dispensationalism and millennial teachings, they regard the amillennial, spiritualising readings of mainstream interpreters as 'the perfect absurdity', a 'delusion'. See Darby (1868:83). and killing the remnant of true believers. Peace will only arrive with the final stage when these powers are eliminated at the final coming of Jesus after the thousand years reign (Lukas 1986). Evil is, furthermore, embodied by the general sociopolitical situation where many dangerous influences are deemed to contribute to loss of faith and social ills.

Having sold millions of copies, these publications further escalated millennium's shift from the margins to the centre of the religious discourse, certainly within evangelical contexts. Contributing to this shift were, furthermore, various other developments, including a blockbuster film named Left Behind, that was an adaptation of Tim LaHaye's book and, starring Nicolas Cage, as well as the concomitant paraphernalia like rapture crockery, clothing and even bumper stickers warning people about drivers being raptured. All these also helped make millennialism into a global sensation, even amongst other religious traditions and faiths outside the North American context. A decisive driving factor was the approach of the year 2000 when these events were expected to take place. This reminded observers of other such movements when significant calendar changes were due, and expectations of the imminent end of the world intensified. ${ }^{5}$ So dominant were the coverage of this movement in religious and secular media that millennialism can be regarded as a major cultural phenomenon that drew the attention of a global audience.

What is most striking, however, is the political nature of this shift. The 'Left Behind'-literature developed a political agenda with frightening, dangerous consequences, as examples from the sociopolitical context of the United States in modern times will show. This political agenda is, however, not entirely unexpected for the informed observer. Millennialism has not been as apolitical as it is often thought. A historical investigation will show that its sociopolitical impact and outcomes were similar to previous historical phases and events and reflect similar dynamics. The challenge in this regard is that this prehistory of contemporary millennialism has been obfuscated exactly by the common assumption that it was first and foremost about a religious, apolitical movement with little interest in this world and its affairs and with a tendency to social and political apathy. An analysis of previously unknown or underutilised sources will show that contemporary millennialism has deep roots in centuries of millennial thought and writings in the early modern period that had major sociopolitical interests and ramifications. Such an analysis further helps to illuminate how millennialism's hermeneutical strategy of dispensationalism has the potential not only to endanger societies and individuals, but, as a direct result and outcome, also to undermine the credibility and even the very existence of the church. This happens where people, claiming the gift of prophecy, wrongly appropriated and promoted millennialist thought to stoke revolt against others or where they predict future events or use conspiracy theories that turn out to be fake or that elicited violent responses by the status quo. Finally, before the 'Left Behind'

5. Historical research reveals that similar hysteria existed at major calendric changes in years 500, 1000 and 1500 (see De Villiers 2017b:339-360 and 2017a:362-377; see also Rossing 2004 and Jewett 1979). 
movement, as it presented in the late 20th century in its attitude towards Israel, will be investigated in the last part of this article as a case study for the sociopolitical nature of millennialism, the context within which it can be understood needs to be provided first. This relates to the earlier situation in the United States, and also to its roots in millennialism in modern England since the 16th century. In a concluding section, separate attention will be given to the relationship of millennialism with Israel because it represents a focal point and also the most dangerous aspect of its political agenda.

\section{Early political millennialism in the United States}

There are several important indications of the sociopolitical nature of millennialist thought in the United States already in the 18th century. As millennialist expectations continued, they also accrued new functions and layers of meaning. They were being used to defend the cause of war, to glorify the special role of the United States in the world and to promote nationalist feelings. In this phase and context, the millennial kingdom of peace that the faithful expected began to resemble a thousand-year reign of religious and civil freedom that had to be defended against opponents, colonial masters or dissenting groups. ${ }^{6}$

Millennialist motifs were used, for example, by both sides in the 19th century to reflect on and justify the civil war. The Battle Hymn of the Republic, written by Julia Ward Howe in November 1861, represented a rallying cry that was formulated in terms of the end time war of the Rider on the White Horse in Revelation 19. The hymn is 'filled with religious images suggesting the millennial imagery so prevalent among Northerners during the war' (Moorhead 2007:s.p.). Christian ministers, observed Moorhead (2007):

$[O]$ ften portrayed the war for the Union in millennial terms. Drawing on the imagery of the twentieth chapter of Revelation and on other portions of the Bible describing the close of history, they depicted a Northern victory that will prepare the way for the coming of God's Kingdom on earth.7 (p. s.p.)

Northerners further argued that the war represents divine judgement of the end times on those who committed the sins of slavery and prepares the reign of peace for the righteous ones (Moorhead 2007):

Thus one Baptist minister, preaching in Philadelphia in 1863, claimed that the defeat of the rebellion would bring a time that the Founding Fathers of the republic 'pictured and dreamed about, and prayed for. It will come with blessings, and be greeted with Hallelujahs, it will be the Millennium of political glory, the Sabbath of Liberty, the Jubilee of humanity'. (p. s.p.)

Northerners also claimed that they were promoting the high values of Christianity, republican institutions and democratic ideals and underlined the special place and role of the United

6.See Judis $(2005: 2-3)$ for examples of these dynamics. He refers to those who transformed 'Biblical millennialism into what historian Nathan Hatch has called America's "civil millennialism"”.

7.Moorhead (2007:s.p.) notes that the role of religion in the civil war has been ignored until recently. But this is an observation that is true for many areas of research in the humanities. This is even more the case with millennialism, being regarded as part of a lunatic fringe of society.
States in bringing civilisation to the world. Southerners, part of the Confederacy, in turn described their struggle against the North as the Armageddon against evil forces. They promoted patriotism, motivating participation in the war with millennial motifs: ' $[b]$ elief that America was preparing the way for the kingdom of God on earth helped to inspire the loyalty of both the Union soldiers and those on the home front.' (Moorhead 2007:s.p.)

These examples indicate how, long before the 'Left Behind' approach, millennial expectations related to and impacted the sociopolitical setting. They were driven by particular political agendas and were used to outline sociopolitical ideals. This would explain their very different and even conflicting forms. Opposite sides in the civil war thus used the same motifs to legitimise conflicting positions, as became clear in the previous paragraph. The arbitrary nature of this appropriation process shows how it is the sociopolitical context that steered and determined the interpretation of the Bible. In this way, religious concerns became subservient to political ideals and motives.

Such arbitrariness is also evident much later in 20th-century events. The terrible sociopolitical outcomes of millenarianism are illustrated by the tragic fate of various millennial groups during this time. There was, first of all, the Jonestown group of which 913 members died of poisoning in Guyana in 1978 under the leadership of Jim Jones, their charismatic leader. There were also sensational events, televised globally on a daily basis, when the Federal Bureau of Investigation (FBI) invaded the compound of the Branch Davidians in Waco, Texas, in 1993 because they regarded it as a dangerous millennialist cult with the result that, after a long standoff, 76 of its members were killed. ${ }^{8}$ In both these cases, there were tragic and deadly sociopolitical consequences and outcomes for these religious groups.

In the last two centuries, there is, finally, the important phase in which American foreign policy was determined by millennialist thinking. This happened, for example, when the war against Iraq was motivated by calling Saddam Hussein a mad man and 'evil leader' who wanted to destroy the United States and America portrayed itself as 'called' by the 'Maker of heaven' and 'Author of Liberty' to spread freedom in the world (Judis 2005:1-7). One recognises the language that is determined by a binary mindset, so typical and characteristic of millennial thought that fed on the binary language and thought of apocalyptic books like Revelation: here America's quest for freedom of all nations

8.See on the latter De Villiers (2018). For more examples, see Pagels (2013), Wilkinson, (2016) and Turner (2019). Noting the political and social aspects of these four groups, Turner wrote about the various groups, 'Manson preached the coming of Helter Skelter, when black people would rise up against white people but spare his followers (all of whom were white). David Koresh claimed that he was the fina Christian prophet, who needed to father lots of children in order to make it all work. Marshall Applewhite, who led the Heaven's Gate cult, near San Diego, persuaded dozens of his followers to commit suicide in order to board a spaceship that would convey them to a "level of existence above human." Bhagwan Shree Rajneesh focussed on the need to create a new society because "the third and final war is on focussed on the need to create a new society because "the third and final war is on its way". Writing about the Lyman Family, she notes how the members were told that the Big Confrontation is coming and that they needed to be ready and, even willing, to die. 'We will be brought to a higher consciousness, or to a better place. The Lyman Family predicted that the world would end on January 5, 1974. On that date, Mel Lyman told us, we would be taken away to Venus. For a report on the late history of the Lyman Family, see Johnston (1985). This report contains insightful references to the high intellectual profile of many of the group's members. 
represents the ultimate struggle between good and evil. Once again such language shows how sociopolitical conditions are coloured by religious conceptions that arise from Protestant millennialism. It reflects, more specifically, in the words of Judis (2005:2), an apocalyptic mentality that goes back to 17th-century England. ${ }^{9}$

These examples require further investigation, as will be carried out now. Such language does not come from nowhere, nor is it merely the result of biblical interpretation. It has roots in the colonial past of the United States. The country was, after all, as a colony of Britain exposed to the religious discourse in England. This requires more attention now.

\section{Millennialism and politics in modern England}

Millennialist eschatology of the 20th century was to a large extent influenced by Darby, a 19th-century pastor from Ireland whose life and writings played a seminal role in the religious discourse of the 20th century to such an extent that Gribben (2016:102) recently came to the surprising conclusion that Darby has become one of the most influential Protestant thinkers after John Wesley, Martin Luther and John Calvin. ${ }^{10}$

Darby's millennialism, including his teaching of the rapture, was, however, part of a larger political and religious discourse in previous centuries during which millennial views had experienced a strong revival. Millennialism that developed fully from the 16th century onwards consistently had a political character. Long before millennialism became well known in the United States, millennialists were deeply engaged in and influenced by English and continental politics. Millennialism in England with the close link of the church to and interest in matters of the state often reflected on and participated in sociopolitical events. In some cases it had similar dangerous consequences as in later times, which needs to be explained in more detail now. ${ }^{11}$ This is not always discussed in the religious debates about millennialism. It is only in recent times that research on underutilised or ignored sources proved that millennialism was well established in England, and, also, that it was closely linked with political developments (De Villiers 2019). This limited exposure to major trends in the religious discourse is partially a result of the distaste that many had for millennial groups and individuals.

The sociopolitical history of England from the 16th century to the 18th century is characterised by bitter, violent, often deadly, religious controversies, conflicts and wars between the state and the church, Catholics and Protestants. ${ }^{12}$ It is in this context

9.Judis argues (2005:2) that other presidents like John Adams, Woodrow Wilson and Roosevelt used similar religious language to talk about America's role in the world.

10.See the informative article by Gribben (2016:102). Gribben (2016:104) refers to millennialism as a 'distinctively American cultural phenomenon'. As a religious phenomenon, however, it has deep roots in Darby's Irish and English contexts.

11.See De Villiers (2019) for a discussion of Darby's role in the spread of millennialism. A key feature of millennialist movements is their drive for missions and witness (see Gribben 2016:104).

12.Apocalypse (2005) notes, ' $[t]$ he sixteenth century, in particular, witnessed an explosion in Mediterranean regions of messianic writing that had strong overtones of apocalypticism. In the wake of the calamitous expulsion of Jewry from Spain and that millennialist interpreters depicted popes and their political associates as personification of end time evil and as bitter enemies of the true church. The opposition of Protestants was to some extent the result of their religious interest in biblical texts about the end times, but since the Reformation it was also influenced by their Protestant resistance against rituals, customs, liturgy and church governance of their opponents. Their response was also a result of the brutal struggles between Protestants and Catholic groups, such as the Thirty Years War (1618-1648) $\cdot{ }^{13}$ It was a time in which the church used its extraordinary political power to eliminate its opponents in massacres that occurred in various places during the war: amongst these were the murder of thousand inhabitants of Münden in 1626, 600 Protestants in 1620 in Valtellina in an incident that caused widespread public outrage and 20000 people in Magdeburg in 1631. ${ }^{14}$

End times expectations played a seminal role in these cultural and religious wars and conflicts. ${ }^{15}$ Wilson (2008) in his informative discussion on religion's role in the Thirty Years War notes:

During the late sixteenth century, Calvinism, largely subsuming the millennial elements from Lutheranism, developed a Providentialist strain that attached symbolic significance to contemporary figures as the embodiment of hopes for divine guidance and even the dawn of a new age. Frederick V was hailed as new king David who would re-establish Jerusalem in Prague. Similar expectations were held of Christian IV of Denmark around 1625, and of Gustavus Adolphus of Sweden around 1630. (p. 480)

This phenomenon is also to be seen in England in later times. The bitter enmity between groups is best illustrated by events during major political changes that occurred when the Catholic King James II was defeated in what is now known as the Glorious Revolution of 1688, 50 years after the death of Mede, the father of British millennialism. ${ }^{16}$ By this time, millennial thought had already permeated the social and political discourse in the country. This is clear when one considers how Protestants came to power under the joint reign of the new Protestant rulers, William III, the Dutch husband of Mary II, the daughter of King James, and solidified their leadership and their positions of power. They made Protestant succession a constitutional requirement with the passing of the Bill of Rights in December 1689 that ensconced the political dominance of Protestant groups. ${ }^{17}$

\footnotetext{
Portugal in the last decade of the fiftenth century messianic calculation and Prcher of the Mediterranean' (see also Popkin 2001:vii-xiv and Bauckham 1978).

13.The war began as a religious struggle between Catholic and Protestant countries before it developed into a larger conflict in which religious matters were no longer the major issue. The war claimed not only the lives of 8 million people, but also caused terrible persecution of dissenting groups. For an overview, see Wilson (2008:473-514).

14.Wilson (2008:489) noted that this incident was used in propaganda to call for vigorous action.

15.See the extensive discussion in Brownlee (2018:169-181).

16. For Mede's millennial approach and his key role in the rise of millennial movements, see De Villiers (2019).

17.See the discussion in Claydon and Claydon (2009:27-42). See for the following part the extensive documentation in Johnston (2011:202-224). He mentions various authors who supported millennialism.
} 
These factions waged their political battles through the use of millennialist language and motifs, portraying their struggle in terms of the onslaught of the evil forces on the elect of God in end times. They vilified their opponents as corrupt and immoral heretics who undermined state authorities. A key example in this regard is the influential interpretation of Gilbert Burnet, bishop of Salisbury, who played an important role in bringing William of Orange to England. Soon after William arrived, Burnet preached a sermon in which he exuberantly praised William's rule before describing developments in that time as the dawn of a new era, for England, and, as is to be expected in millennialist thought with its absolutist language, also for Europe and the world. Alluding to Revelation 21:1-2, he proclaimed the Revolution as the arrival of the new Heaven and new Earth.

Burnet's acclamation of William and Mary's reign in millennialist language was not unique (Johnston 2011):

Far from being solely the rhetoric of radicalism and dissent, apocalyptic convictions were used by Anglican authors to affirm the significance of the results of the Revolution in the victory of Protestant monarchy and the established church. (p. 202)

An example in case was Benjamin Woodroffe (1638-1711), a well-known Anglican theologian and church leader from a well-educated family of theologians. His social status is clear from the fact that he became chaplain to James, Duke of York, at a young age, and, eventually, to king Charles II. In several publications, he vilified Roman Catholics ${ }^{18}$ as the embodiment of the evil of the last times. His concern was about the political dangers they posed - a fear that was common amongst Protestants who, after the Gunpowder Plot in 1605 and the Popish Plot in 1678-1681, suspected Catholics of wanting to overthrow Protestant kings. In The Fall of Babylon, a book from 1690 about the Antichrist, he argued that the Antichrist would usurp temporal authority in cohorts with Roman Catholics and that the end times were imminent. ${ }^{19}$

Other, more radical millennial views also developed in these times, with much more dangerous consequences. Amongst these were radical groups like the Fifth Monarchy Men who believed that Daniel's four kingdoms of the last times (Dn 2) will be replaced by the millennium at the second coming of Jesus. This conviction lies behind their decision to name themselves the 'Fifth Monarchy Men'. Some of their more radical leaders wanted to overthrow the state. Twice, in 1657

18.See Tappe (2006:153-174) and Johnston (2011:209). See Clogg (2018) for a discussion on Woodroffe's criticism of Roman Catholicism, his intention to train Greek Orthodox groups in his Greek College to resist Roman Catholicism, his rejection of the veneration of Mary, icons and invocation of the saints, as well as rejection of the veneration of Mary, icons and inv
the harsh conditions he imposed on the students.

19.Using Revelation 11:2-3; 12:6, Burnet calculated that the end would happen in 1715 when the 1260 years of Antichrist's reign mentioned in Revelation 11:2-3 would come to an end. Like many other interpreters of Revelation, he began his calculation from 455 CE when the Vandals defeated the last emperor in Rome. Later he argued the calculation of the time should be done in terms of 12 months of 30 days. As a result, he revised his initial calculation from 1715 to 1697 . Thomas Beverley, another Anglican author who shared Woodroffe's apocalyptic perspective and polemica approach, also wrote extensively a approach, also wrote extensively about the relevance of Revelation for his time, and also determined 1697 as the date for the end. Beverley wrote several expositions of Revelation to motivate his separation from the Church of England with sophisticated calendric arguments. He linked Revelation with the history of Rome, but regarded the last, evil phase, associated with the seventh trumpet, as a history of the Roma Catholic church. Later on, he used the book to legitimise the Protestant era inaugurated by the reign of William and to promote the cause of dissenting Protestants again the Church of England (see Johnston 2006:209). and 1661, they sought to hasten the coming of the millennium with a violent uprising (Sell 2013:240). Though this group was a minority and was heavily criticised for their radical actions, they do illustrate how radical the political nature of millennialism could become.

The apocalyptic mindset did not disappear in the time after the Revolution when there seems to have been less of a desire to vilify opponents. Roman Catholicism (or 'popery' as it was also known) was no longer seen as such a serious threat to Protestants. It only took on a different form. Now groups within the same faith community turned against each other, using millennial motifs and thoughts against each other. Some members of the Church of England, for example, vilified their opponents within the church for their support of tithing, regulation of ministerial ordination, control of worship, royal authority, elaborate liturgy and even clerical garments that were too Catholic for them (Johnston 2011:173174). Presbyterians also were attacked as the real enemies of the church and as the embodiment of evil. They were accused of seditious practices, inciting their flock through apocalyptic language and imagery to rebel against the legitimate political order (Johnston 2011:181).

This mixture of historical, literary and political elements shows how end time expectations were used by many in this period to describe and evaluate contemporary political events and developments. Although exegetes were aware of the huge historical gap between the time in which the book originated and in which they were reading it, it did not prevent them from using the text indiscriminately to address their own political agenda and to fight their own political battles with and in the name of end expectations (Johnston 2006:174). All this, finally, shows that millennialism is by no means apolitical or purely religious.

\section{Jerusalem and Israel in the millennium}

The political nature of millennialism is closely linked with and clearly illustrated in its conceptualisation of Israel's place and role in the end times (Shuck 2009:40). This will reiterate the above findings that millennialism can have a highly political character. This requires more attention now.

\section{The roots}

From earliest times Israel and Jerusalem had a key place in end time events, based on the expectation of a new Jerusalem in Revelation 21, and also because of the fulfilment of the divine promises to the people of God in Hebrew Scriptures. In the second century, to name but two examples, Justin Martyr (Dial. Tryph. 80) wrote that the millennium will take place in the rebuilt, new Jerusalem and Irenaeus interpreted passages like Isaiah 65:20-25 as referring to the reign of the Antichrist in Jerusalem before it will be destroyed by Christ. The millennium will begin with the resurrection of the saints and will be based in Jerusalem as the capital of the world. At the end of the millennium, the new Jerusalem will replace the 
old one (Adv. Haer. 5.32 and 30.4). These remarks show how the Jewish people and Israel were a firm part of millennialist expectations from earliest times.

\section{Jerusalem and Israel in millennialism of early modern Europe}

This view of Israel's place in the end times was again prominent in millennialism in early modern England. Of special relevance was the notion that Jews will convert to Christianity and be restored as people of God. Jue (2008:20) notes that most millennialists of the 16th century in the United Kingdom expected a mass conversion of the Jews before the arrival of the millennium. The conversion of the Jews was also a fixed topos in the future expectations of 17th-century authors like Alstedt, Mede and others (Wainwright 2001:68). Masselink (1930:20-30) noted how prominent this teaching was in Germany and Holland in the 18th century where a large number of authors linked their expectation of the Parousia of Christ with the restoration of the land to Israel and the end time conversion of the Jews. Christians in these countries expected a millennial kingdom with Jerusalem and the new temple as its centre and an interim kingdom from the time of the saints' rapture (1 Th 4:17-18 and Rv 20:1-60) until the final judgement with the establishment of the kingdom of God. Christ will reign over the Jews after they convert to Christianity.

It is at this point that a new development on the political front began to shape millennial expectation of the future in a new manner. This has to do with the political situation of Jews: there were for many centuries very few Jews present in Israel and little indication that there will be a Jewish state in the country again. This changed as, from the 19th century onwards, millennial theologians in the United Kingdom began to embrace the physical restoration of the Jews to Israel. Powerful individuals with millennialist sympathies actively promoted this ideal in the United Kingdom by supporting Zionism, followed shortly thereafter by a similar campaign in the United States (1998:4). ${ }^{20}$

These observations illustrate how the views of Jews' place and role in the end times had far-reaching social and political consequences long before the 'Left Behind' movement. Most important, though, was the indelible conviction that the Jews had a vital role to play in end times. It was so entrenched in millennialist thought that some supported and promoted the idea of Jews returning to the land to set up the state of Israel. Thus, a process of setting up a state of Israel began in the 19th century that would have immense sociopolitical ramifications in the next century - as will be explained next.

20.This development is striking, given the anti-Semitic feelings that existed also among some Christian groups. An example is the often heartless attitude towards the fate of the Jews in Germany in the Second World War. During the second quarter of the 20th century, The Protocols of the Elders of Zion, a fake document about a Jewish plan to destroy Christian civilisation, began to circulate in Europe and the United States. Many dispensationalists, recognising the Protocols as anti-Semitic propaganda, condemned the Nazi persecution of the Jews. And yet, some of them regarded the deaths of Jews as an inevitable result of God's plan for the future regarded the deaths of Jews as an inevitable result of God's plan for the future (Weber 1998:4). Others, scandalously, even stated that 'Hitler and the Nazis were God's instruments of judgment' and that God was using Hitler 'to increase the Jews' desire for a homeland of their own in Palestine'. Weber (1998:3-4) notes comment by Rimmer, ' $[b] y$ driving the preserved people back into the preserved land, Hitler, who does not believe the Bible ..., is helping to fulfil its most outstanding prophecy'. Equally shocking was that dispensationalists sometimes took comfort in their belief that persecution made Jews more susceptible to the gospel.

\section{The 'Left Behind' view of Israel and its dangerous consequences}

In a historical overview of the relationship between Israel and Modern Evangelicals in the United States, Weber (1998) also noted their firm belief that Israel will be the centre of events with the return of Christ. Evangelicals, influenced by their millennial sympathies, were convinced that history will unfold in dispensations. Taking their cue from the prophecy of Seventy Weeks in Daniel 7-9, they distinguished between the history of Israel as the earthly people who will be subjected to four successive gentile rules until, in the 'seventieth week', the Messiah will return to re-establish David's throne and conquer the last ruler who wants to destroy Israel. This history is to be separated from the history of the church. The church was to be the new people of God after the Jews rejected Jesus. Weber (1998) notes:

Since God had decided to work with only one group at a time, God must remove the church from the earth before focusing attention again on the Jews. After Jesus comes for his saints in the 'Rapture' (1 Thess. 4:13-17), the prophetic clock starts ticking again. Once the church is gone, Daniel's Seventieth Week (the 'great tribulation' of Matt. 24, 2 Thess. 2, and Rev.) can begin, after which Jesus will return with his already raptured saints to defeat Antichrist, the great persecutor, and establish his millennial reign. (p. 1)

This belief is part of a larger discourse that permeates American culture, as Weber (1998:2) notes. This larger narrative, characterised by a pessimistic view of society, posits an end scenario in which, after the Jews are gathered in Israel, there will be an irreversible decline in morals, the disintegration of family life, economic crises, wars and epidemics, together with extreme natural disasters. Then, after the rapture of the church, the Antichrist will appear as a charismatic, peaceloving leader who will head a 10-nation confederacy in western Europe in alliance with Israel (who is unaware of his true identity). When his true identity is revealed, the Antichrist is joined by a False Prophet, a powerful religious leader, to persecute the remaining Christians. The Antichrist will be conquered by Christ, the Jews will accept Jesus as Messiah and the Messiah will rule over the world from Jerusalem with its renewed temple and restored sacrificial system.

This special place of the Jews remained a firm part of the 20thcentury millennialism. The Jews will be in Israel in the last dispensation, after the rapture of the saints, to occupy Jerusalem and to renew the temple (Lukas 1986). Despite their rejection of the gospel, the Jews will retain their special place in God's plan for the world. This has been such an integral part of the future expectations of millennialism that it was stated that the end could not begin until the Jews have returned to Israel. This interest in the political status of Israel increased in the second half of the 20th century in the 'Left Behind' texts. It was a time in which powerful dispensationalists in the United States openly and vigorously supported Israel.

It is a support that has severe social and political ramifications. It showed how millennialism and evangelical groups were 
radicalised politically. In 1970, for example, in his Late Great Planet Earth, Hal Lindsey explained all the traditional endtime characters and events in terms of contemporary realities. He sketched an end-time scenario with a comprehensive political nature in which the role players are the large, powerful world powers of his times. They include the European Union (then the European Economic Councel [EEC]), the Soviet Union, China and an Arab-African coalition that represent the end-time villains that will conspire and wage war against the church. The whole setup is further complicated by the expectation that the end of the present dispensation and world was imminent. Interpreters like Lindsey have given up on their world. They are deeply pessimistic, firmly convinced that the present is irredeemable and in a steep decline. Concretely, the world is in ruins because of materialism, immorality and other social ills (Weber 1998:4-5). Ten years later, Lindsey wrote a second, darker book with the title, The 1980s: Countdown to Armageddon, in which he developed a full-blown political agenda. In this work, he attacked liberal groups for their dismantling of the military and for undercutting free enterprise. Against them he stressed that America needed capitalism, he added, especially because it will provide the resources to defend Israel.

Such views resonated with powerful groups in social and political spheres of the United States, indicating their potential to determine political trends. Despite the fact that the expectations failed to realise, Lindsey became a sought-after speaker, amongst others, at the Pentagon and for Israeli government officials. Other indications are that these 'Left Behind' groups are helping to shape Middle Eastern policies of the US government and to promote a strong pro-Israel position. They have little regard for the negative consequences of their pro-Israel position, ignoring, for example, the dismal lot of the Palestinians, avoiding critique of Israel's harsh treatment of them and overlooking the dangerous consequences of nuclear proliferation and militarisation of rogue states.

More disconcerting is the lackadaisical attitude towards war that is implicit in this ideology. The impression is that war in the Middle East is regarded as unavoidable, if not necessary. Without war in the Middle East, the end events will not take place. Even the idea that war could lead to the extinction of the planet seems to be a non-issue for them because the planet is in any case going to be destroyed in the end time. One could extrapolate this concern to other burning issues, like climate change, the arms race and pollution. In terms of this millennialism, it really makes no sense to be overtly concerned about it because this polluted world is in any case doomed.

\section{Conclusion}

Millennialism could easily create the impression that it is first and foremost about a religious topos about end times that is of concern to individuals and marginal groups. It may seem a harmless topos, as it intends to succour those who live in difficult times. And yet, history shows that millennialism also had a darker side. Its agonistic mindset also created anxiety about being surrounded by malicious, conniving evildoers who wish to eliminate the forces of good. This anxiety has the potential to promote vengeance when people want to claim agency in and make true the promised destruction of evildoers by terrible plagues, killings and holocaust of fire. Their mechanical, deterministic understanding of the end could all too easily rationalise suffering of people as divine judgement for past sin. In contemporary times (Lukas 1986):

$[T]$ he Book of Revelation has served less to comfort the afflicted than to buttress the self-righteous. For it appeals to those who divide the world between absolute good and absolute evil, between the followers of the Lord and the followers of Satan. For such people, nuclear war may appear to be the Armageddon that the Book of Revelation promised and Rapture the device by which they will be saved while all others are eternally damned ... And this, in turn, promotes a kind of apocalyptic fatalism. (s.p.)

In a world divided between good and evil, 'accommodation or negotiation with the enemy becomes unthinkable ... peace is humanly impossible, and war inevitable' (Lukas 1986). ${ }^{21}$ Such are some of the dangerous consequences of millennialism.

\section{Acknowledgements}

The author wishes to honour Eben Scheffler not only for his academic work in the field of biblical studies but also as a colleague and friend over many years.

\section{Competing interests}

The author has declared that no competing interests exist.

\section{Author(s) contributions}

Pieter G.R. de Villiers is the sole author of this article.

\section{Ethical consideration}

The author confirms that no ethical clearance was required for this study.

\section{Funding information}

This study was supported by the National Research Foundation.

\section{Data availability statement}

Data sharing is not applicable to this article as no new data were created or analysed in this study.

\section{Disclaimer}

The views and opinions expressed in this article are those of the authors and do not necessarily reflect the official policy or position of any affiliated agency of the authors.

\section{References}

Apocalypse: Medieval Jewish Apocalyptic Literature, 2005, Encyclopedia of religion viewed 18 June 2019, from https://www.encyclopedia.com/environment/ encyclopedias-almanacs-transcripts-and-maps/apocalypse-medieval-jewishapocalyptic-literature.

21.See also slade (2016) for an extensive critique of millennial ideology. 
Bauckham, R., 1978, Tudor Apocalypse: Sixteenth century apocalypticism millenarianism and the English Reformation from John Bale to John Foxe and millenarianism, and the English Reformation from
Thomas Brightman, Sutton Courtenay Press, Oxford.

Benware, P.N., 2006, Understanding end times prophecy: A comprehensive approach, Moody, Chicago, IL.

Brownlee, V., 2018, Biblical readings and literary writings in Early Modern England 1558-1625, Oxford University Press, Oxford.

Claydon, A.M. \& Claydon, T., 2009, 'The recent English historiography of the Glorious Revolution', Odysseus 1(1), 27-42.

Clogg, R., 2018, Greek to me: A memoir of academic life, Tauris, London, New York.

Collins, J.J., 1993, Daniel: A commentary, Fortress, Minneapolis, MN.

Darby, J.N., 1868, Lectures on the second coming, Broom, London.

De Villiers, P.G.R., 2017a, 'Reading Revelation from the top or the underside', Stellenbosch Theological Journal 4(2), 362-377.

De Villiers, P.G.R., 2017b, 'Reading the Book of Revelation politically', Stellenbosch Theological Journal 4(2), 339-360.

De Villiers, P.G.R., 2018, 'The spirituality of apocalyptic and millenarian groups. The case of the Branch Davidians in Waco', HTS Teologiese Studies/Theological Studies 74(1), a5152. https://doi.org/10.4102/hts.v74i3.5152

De Villiers, P.G.R., 2019, 'Millennialism, rapture and Left-Behind-Literature. Analyzing a major cultural phenomenon in recent times', Stellenbosch Theological Journal 5(1), 163-190.

Gribben, C., 2016, 'John N. Darby, Dispensational eschatology and the formation of Trans-Atlantic Evangelism', Schweizerische Zeitschrift für Religions- und Kulturgeschichte (110), 99-109.

Jewett, R., 1979, Jesus against the rapture: Seven unexpected prophecies, Westminster, Philadelphia, PA.

Johnston, D., 1985, Once-Notorious '60s commune evolves into respectability: After 19 years the Lyman Family prospers as craftsmen and farmers', Los Angeles Times, 04 August, viewed 18 June 2019, from https://www.latimes.com/archives/la04 August, viewed 18 June 2019, from
xpm-1985-08-04-vw-4546-story.html.

Johnston, W., 2006, 'Thomas Beverley and the "Late Great Revolution": English Apocalyptic expectation in the late seventeenth century', in A. Hessayon \& N. Keene (eds.), Scripture and scholarship in Early Modern England, pp. 158-175, Ashgate, Aldershot.

Johnston, W., 2011, Revelation restored: The Apocalypse in later seventeenth-century England, Boydell, Woodbridge.

Judis, J.B., 2005, 'The chosen nation: The influence of Religion on U.S. Foreign Policy', Policy brief, Carnegie endowment for international peace, viewed 21 June 2019, from https://carnegieendowment.org/files/PB37.judis.FINAL.pdf.

Jue, J.K., 2008, 'Puritan Millenarianism in Old and New England', in J. Coffey \& P.C.G. Lim (eds.), The Cambridge companion to Puritanism, Cambridge University Press, Cambridge.
Kovacs, J. \& Rowland, C., 2004, Revelation, Blackwell, Malden, MA, Oxford.

Lukas, J.A., 1986, 'The rapture and the bomb', New York Times, 08 June, viewed 17 June 2019, from https://www.nytimes.com/1986/06/08/books/the-rapture-andthe-bomb.html.

Maier, H.O., 2003, Apocalypse recalled. The Book of Revelation after Christendom, Fortress, Minneapolis, MN

Masselink, W., 1930, Why thousand years?, Eerdmans, Grand Rapids, MI.

Moorhead, J.H., 2007, Religion in the Civil War: The Northern perspective, viewed 01 February 2019, from http://nationalhumanitiescenter.org/tserve/nineteen/nkeyinfo/ cwnorth.htm.

Pagels, E.H., 2013, Revelations. visions, prophecy and politics in The Book of Revelation, Penguin, New York.

Popkin, R.H., 2001, 'Introduction', in M. Goldish and R.H. Popkin (eds.), Jewish Messianism in the early modern world, pp. viii-xiv, Springer Science+Business Media, Dordrecht.

Rossing, B.R., 2004, The rapture exposed: The message of hope in the Book of Revelation, Westview, Boulder, CO.

Sell, A.P.F., 2013, Confessing the faith. Yesterday and today. Essays Reformed, Dissenting and Catholic, James Clarke, Cambridge.

Shuck, G.W., 2009, Marks of the beast: The left behind novels and the struggle for Evangelical identity, New York University Press, New York, London.

Slade, D.M., 2016, Critical book review: For Zion's Sake Christian Zionism and the role of John Nelson Darby by Paul Richard Wilkinson, viewed 28 November 2018, from http://www.academia.edu/26338835/For_Zion_s Sake_Christian_Zionism_and the_Role_of_John_Nelson_Darby_-_by_Paul_Richard_Wilkinson.

Tappe, E.D., 2006, 'The Greek College at Oxford, 1699-1705', in P.M. Doll (ed.), Anglicanism and orthodoxy: 300 years after the 'Greek College' in Oxford, pp. 153-174, Peter Lange, Oxford.

Turner, G., 2019, 'My childhood in a cult', The New Yorker, 29 April, Consulted 18 June 2019.

Wainwright, A.W., 2001, Mysterious Apocalypse: Interpreting the Book of Revelation Wipf and Stock, Eugene, OR.

Weber, T.P., 1998, 'How Evangelicals became Israel's best friend', Christianity Today, 05 October, pp. 1-8, viewed 20 June 2019, from https://icjs.org/sites/default/files/ Weber $\% 20$ on $\% 2$ How $\% 20$ Evangelicals $\% 20$ Became $\% 2$ Israel $\% 27 \mathrm{~s} \% 20$ best $\% 20$ Friend $\% 20$ from $\% 20$ Christ.w20Today.pdf.

Wilkinson, A., 2016, 'The "Left Behind" series was just the latest way America prepared for the rapture', The Washington Post, 13 July, Consulted 14 March 2019.

Wilson, P.H., 2008, 'Dynasty, constitution, and confession: The role of religion in the Thirty Years War', The International History Review 30(3), 473-514. https://doi.org/ 10.1080/07075332.2008.10415483 